\title{
Validation of Prototype Research Software- Infant Prakriti Assessment (PRS-IPA): Inferences from A Cross Sectional Pattern
}

\author{
Srivastava Niraj, Singh Praguna, Gehlot Sangeeta, Singh Sanjay, Singh B.M.
}

\begin{abstract}
Introduction: Prakriti determination in an infant helps to live more healthy and prosperous life by changing their rearing plan accordingly to prevent onset of related disorders in future. Validation under this study was planned to evaluate the agreement between Infant's Prakriti Assessment questionnaire (IPAQ) and PRS-IPA (Prototype Research Software-Infant Prakriti Assessment), a software for Prakriti assessment in infants.

Materials and methods: A cross sectional study was carried out in Sir Sunderlal Hospital BHU and data were analyzed through two step Prakriti determination process i.e. first, by Infant's Prakriti Assessment questionnaire (IPAQ) and second by PRS-IPA. Validation was done by Spearman's Rank Correlation Coefficient and Cohen's kappa coefficient.

Observations and Result: In this study, Cohen's kappa coefficient was found 0.955 which is highly significant. Prakriti assessed by PRS-IPA software is valid. Validation by Spearman's Rank Correlation coefficient was also found highly significant $(p=0.000)$.

Discussion \& Conclusion: The data, derived from spearman's and kappa suggest its validity and PRS-IPA can be used for the Prakriti assessment with accuracy in infants.
\end{abstract}

Keywords: Ayurveda, Prakriti, Physical constitution, PRS IPA, Infant, questionnaire, Validation, Software.

\section{INTRODUCTION}

Ayurveda, 5000 years old system of medicine that has its origins from Vedic culture of India, explains the uniqueness of individuals by means of Prakriti (Physical constitution). According to this system Prakriti (Physical constitution) determines the predisposition with prognosis to diseases in addition to therapy and life-style regime.

Prakriti assessment with other factors of Dashavidha Pariksha provides total understanding of patient or healthy individuals [1].

Revised Manuscript Received on March 16, 2020.

* Correspondence Author

Srivastava Niraj*, Professor, Department of Kaumarbhritya / Balroga, Sardar Patel Institute of Ayurvedic Medical Sciences \& Research Centre. Lucknow, Uttar Pradesh 226002, India. Mobile. No. 9473662858. Email:nirajimsbhu@gmail.com

Singh Praguna, Software developer, SAP Lab Bangalore, Karnataka.

Gehlot Sangeeta, Professor and Head, Department of Kriya Sharir, Faculty of Ayurveda, IMS, BHU, Varanasi, India.

Singh Sanjay, Professor, Department of Computer Science, IIT, BHU, Varanasi, India.

Singh B. M., Professor and Head, Department of Kaumarbhritya/Balroga, Faculty of Ayurveda, IMS, BHU, Varanasi, India.

Gehlot Sangeeta, Professor and Head, Department of Kaumarbhritya/Balroga, Faculty of Ayurveda, IMS, BHU, Varanasi, India.

(C) The Authors. Published by Blue Eyes Intelligence Engineering and Sciences Publication (BEIESP). This is an open access article under the CC BY-NC-ND license (http://creativecommons.org/licenses/by-nc-nd/4.0/)
Prakriti is sum total of physical, physiological and psychological characteristics of any individual and represents the genotype [2]. Knowledge of Prakriti can be helpful for diagnosis of diseases [3], management of disease, [4] forecast the proneness for future disorders [5] and prevention from many chronic diseases. Knowledge of Prakriti can steer the parents for anticipation of expected disorders in their children [6].

Prakriti is a unique, but definite constant traits manifested in persons and these specific types of Doshika Prakriti can be identified in growing individuals [7].

Prakriti of an individual is fixed at the time of conception by predominance of Dosha in the Shukra (sperm) and Shonita [8] (ovum) but Acharya Charaka opines that it is not only dominance of Dosha in Shukra and Shonita but certain other factors like Kala-Garbhashaya (time factor and condition of uterus) Maturaaharavihara (diet and code of conduct of mother) and Panchamahabhuta vikara (condition of Panchamahabhuta) are also responsible for determination of Prakriti [9]. Prakriti assessment of any infants has a decisive role in maintenance of health and cure of the disease, which is the prime objective of Ayurveda [10]. In Ayurveda seven broad constitutions (Prakriti) have been described each with a varying degree of tendency to different diseases [11].

Information technology (IT) has a broad scope in upgradation of academic, hospital and research sector of AYUSH. Information technology uses computers and software to manage patients' information. Ayurveda is restricted due to language factor for globalization; therefore there is urgent need of software in Ayurveda. Presently, questionnaire is most accepted tool to determine individual Prakriti (Physical constitution).

PRS-IPA (Prototype Research Software-Infant Prakriti Assessment) is software for Prakriti determination in infants which is prepared under the collaboration of Department of Kaumarbhritya/Bal Roga, Department of Kriya Sharir, and Department of computer science, IIT-BHU, Varanasi to save the time, reutilization of stored data for future use including individualized management and prevention of forthcoming Prakriti prone disorders [12]. Therefore, this study was planned to validate and evaluate the agreement between Infant's Prakriti Assessment questionnaire (IPAQ) and PRSIPA (Prototype Research Software-Infant Prakriti Assessment), software for Prakriti assessment in infants.

\section{MATERIAL AND METHOD}


Validation of Prototype Research Software- Infant Prakriti Assessment (PRS-IPA): Inferences from A Cross Sectional Pattern

A. Objective of study: Validation and reliability of newly developed software PRS-IPA (Prototype Research Software-Infant Prakriti Assessment).

B. Ethical clearance: The ethical committee clearance number was dean/2011-12/392-A dated on 12/12/2011

C. Population and Sample: A cross sectional study was carried out in Kaumarbhritya/Balroga, O.P.D., Sir Sunderlal Hospital, Institute of Medical Sciences (I.M.S), Banaras Hindu University (BHU) after obtaining approval from the institute ethical committee. 226 healthy infants were selected after written informed consent by parents after explaining about the study and its aims. After proper screening Prakriti assessment was done on $10^{\text {th }}$ day of life (time of registration) in healthy state by Infant's Prakriti Assessment Questionnaire (IPAQ) and developed software PRS-IPA during research work. PRS-IPA software has same questions as in Infant's Prakriti Assessment Questionnaire (IPAQ).

D. Assessment of Prakriti by Questionnaire Performa: For this study, an Infant's Prakriti Assessment Questionnaire (IPAQ) was prepared on the basis of Prakriti characteristic mentioned in different textbooks of Ayurveda [13][14][15] [16] [17] [18] [19][20]. In questionnaire, only those Doshika characteristics were taken, which were possible to assess at infantile age group; while the other were excluded [21]. Infant's Prakriti Assessment questionnaire (IPAQ) was already validated by Prakriti assessing proforma of Department of Kriya Sharir [22]. Assessment was done after analysis of obtained data filled by questionnaire and physical examination of infants. All concerned characteristics were assessed by Trividha Pariksha of Ayurveda as Darshan (inspection), Sparshana (palpation) and Prashna (question) [23] [24].

Infant's Prakriti Assessment questionnaire (IPAQ):

Table l: Feeding habits

\begin{tabular}{|l|l|l|l|l|l|}
\hline S.N. & Questions & $\begin{array}{l}\text { Age of } \\
\text { Assessment }\end{array}$ & Vataja Prakriti & Pittaja Prakriti & Kaphaja Prakriti \\
\hline 1. & Baby like & $\begin{array}{l}\text { From } \\
\text { registration }\end{array}$ & 1. Variable & $\begin{array}{l}\text { 1.Cold milk/Cold } \\
\text { food }\end{array}$ & $\begin{array}{l}\text { 1. Wam } \\
\text { milk/Hot food }\end{array}$ \\
\hline 2. & $\begin{array}{l}\text { Condition of } \\
\text { baby to feed }\end{array}$ & $\begin{array}{l}\text { From } \\
\text { registration }\end{array}$ & $\begin{array}{l}\text { 2.Sometimes cry } \\
\text { sometimes no cry }\end{array}$ & 2. Excessive cry & $\ldots \ldots \ldots \ldots . . . .$. \\
\hline 3. & $\begin{array}{l}\text { Feeding per } \\
\text { day }\end{array}$ & $\begin{array}{l}\text { From } \\
\text { registration }\end{array}$ & $\begin{array}{l}\text { 3. Increased } \\
\text { frequency with } \\
\text { variable amount }\end{array}$ & $\begin{array}{l}\text { 3. Increased } \\
\text { frequency and } \\
\text { amount }\end{array}$ & $\begin{array}{l}\text { 2. Less than } \\
\text { optimum }\end{array}$ \\
\hline 4. & $\begin{array}{l}\text { Quantity of } \\
\text { intake per feed }\end{array}$ & $\begin{array}{l}\text { From } \\
\text { registration }\end{array}$ & 4.Irregular & 4. Fairly good & 3.Low intake \\
\hline
\end{tabular}

\section{Table 2: Borvel and urine habits}

\begin{tabular}{|l|l|l|l|l|l|}
\hline S.I. & Questions & $\begin{array}{l}\text { Age of } \\
\text { Assessment }\end{array}$ & Vatuja Prakriti & Pittaja Prakriti & Kaphaja Prakriti \\
\hline 1. & $\begin{array}{l}\text { Frequency of } \\
\text { stool per day } \\
\text { (in relation to } \\
\text { consistency; } \\
\text { smell and } \\
\text { color) }\end{array}$ & $\begin{array}{l}\text { From } \\
\text { registration }\end{array}$ & - & $\begin{array}{c}\text { Excess secretion } \\
\text { of stool }\end{array}$ & - \\
\hline 2. & $\begin{array}{l}\text { Frequency of } \\
\text { urine }\end{array}$ & $\begin{array}{l}\text { From 3rd } \\
\text { month }\end{array}$ & - & Excess urination & - \\
\hline
\end{tabular}

Table 3: Thirst habits

\begin{tabular}{|l|l|l|l|l|l|}
\hline S.N. & Question & $\begin{array}{l}\text { Age of } \\
\text { Assessment }\end{array}$ & Vataja Prakriti & Pittaja Prakinit & Kaphoja Prakiti \\
\hline 1. & Thirst (dalily) & After 6 month & $\cdot$ & $\begin{array}{l}\text { More in } \\
\text { frequency }\end{array}$ & $\begin{array}{c}\text { Less in frequency } \\
\text { and tolerable }\end{array}$ \\
\hline
\end{tabular}

Table 4: Srreating habits

\begin{tabular}{|l|l|l|l|c|l|}
\hline S.N. & Questions & $\begin{array}{l}\text { Age of } \\
\text { Assessment }\end{array}$ & Vataja Prakriti & Pittuja Prakinit & Kaphaja Prakriti \\
\hline 1. & Sweating & After 3month & - & $\begin{array}{c}\text { More in volume } \\
\text { and frequency }\end{array}$ & $\begin{array}{c}\text { Less in volume and } \\
\text { frequency }\end{array}$ \\
\hline 2. & $\begin{array}{l}\text { Smell of } \\
\text { sweating }\end{array}$ & After 3month & Variable & Foul smell & - \\
\hline
\end{tabular}

\section{Table 5: Sleep habits}

\begin{tabular}{|c|l|l|c|c|c|}
\hline S.I. & Questions & $\begin{array}{l}\text { Age of } \\
\text { Assessment }\end{array}$ & Vataja Prakriti & Pittaja Prakriti & Kaphhaja Prakiti \\
\hline 1. & $\begin{array}{c}\text { Period of sleep } \\
\text { in hours }\end{array}$ & $\begin{array}{l}\text { From } \\
\text { registration }\end{array}$ & Less sleep & - & More sleep \\
\hline
\end{tabular}


Table 6: Physical activity

\begin{tabular}{|c|c|c|c|c|c|}
\hline S.N. & Questions & $\begin{array}{l}\text { Age of } \\
\text { Assessment }\end{array}$ & Vataja Prakriti & Pittaja Prakriti & Kaphaja Prakriti \\
\hline 1. & Activity level & After 3 month & $\begin{array}{l}\text { Sometimes very } \\
\text { active some time } \\
\text { dull }\end{array}$ & - & Dull in activities \\
\hline 2. & $\begin{array}{l}\text { Tolerance to } \\
\text { painful } \\
\text { stimuli } \\
\text { (Cold) }\end{array}$ & After 6 month & Low tolerance & No tolerance & High tolerance \\
\hline 3. & $\begin{array}{l}\text { Level of } \\
\text { anger }\end{array}$ & After 9 month & $\begin{array}{l}\text { Early onset of } \\
\text { anger and early } \\
\text { subside }\end{array}$ & $\begin{array}{l}\text { Excess and quick } \\
\text { onset of anger }\end{array}$ & $\begin{array}{l}\text { Delayed onset of } \\
\text { anger and late } \\
\text { subside }\end{array}$ \\
\hline 4. & Attachment & After 6 month & $\begin{array}{l}\text { Earl attachment } \\
\text { and early } \\
\text { detachment }\end{array}$ & - & $\begin{array}{l}\text { Delayed } \\
\text { attachment and } \\
\text { delayed } \\
\text { detachment }\end{array}$ \\
\hline 5. & $\begin{array}{l}\text { Movement of } \\
\text { joints, eye, } \\
\text { lips, tongue, } \\
\text { head, palm } \\
\text { and sole }\end{array}$ & After 6 month & $\begin{array}{l}\text { Light, fast, } \\
\text { unsteady and } \\
\text { early onset }\end{array}$ & - & Slow and steady \\
\hline 6. & After bathe & After 3 month & - & $\begin{array}{c}\text { Early becomes } \\
\text { dry }\end{array}$ & Late becomes dry \\
\hline
\end{tabular}

Table 7: Speech/Voice habits

\begin{tabular}{|l|l|l|l|l|l|}
\hline S.N. & Question & $\begin{array}{l}\text { Age of } \\
\text { Assessment }\end{array}$ & Vataja Prakriti & Pittaja Prakriti & Kaphaja Prakriti \\
\hline 1. & $\begin{array}{l}\text { Tendency to } \\
\text { talk (as } \\
\text { informed by } \\
\text { mother) }\end{array}$ & $\begin{array}{l}\text { After 6 } \\
\text { month }\end{array}$ & $\begin{array}{l}\text { Over talkative, } \\
\text { irrelevant talk }\end{array}$ & $\ldots \ldots \ldots \ldots \ldots . . .$. & Less talkative \\
\hline 2. & Voice quality & $\begin{array}{l}\text { After 3 } \\
\text { month }\end{array}$ & $\begin{array}{l}\text { Continuous rough } \\
\text { weak, unpleasant } \\
\text { and hoarse }\end{array}$ & - & Affectionate voice \\
\hline 3. & $\begin{array}{l}\text { Weather } \\
\text { tolerance }\end{array}$ & $\begin{array}{l}\text { After 3 } \\
\text { month }\end{array}$ & $\begin{array}{l}\text { Intolerance to } \\
\text { cold }\end{array}$ & $\begin{array}{l}\text { Intolerance to } \\
\text { heat }\end{array}$ & Intolerance to cold \\
\hline
\end{tabular}

\section{Table \&: Disease Incidence}

\begin{tabular}{|c|c|c|c|c|c|}
\hline S.I. & Question & \begin{tabular}{|l|} 
Age of \\
Assessment
\end{tabular} & Vataja Prakinit & Pittuja Prakitit & Kaphaja Prakiti \\
\hline 1. & $\begin{array}{l}\text { Incidence of } \\
\text { disease }\end{array}$ & $\begin{array}{l}\text { After 3 } \\
\text { month }\end{array}$ & Highincidence & - & $\begin{array}{l}\text { Low incidence but } \\
\text { chronic and severe } \\
\text { form }\end{array}$ \\
\hline 2. & $\begin{array}{l}\text { Type of } \\
\text { disease }\end{array}$ & $\begin{array}{l}\text { After3 } \\
\text { month }\end{array}$ & $\begin{array}{l}\text { Sufferer vith cold, } \\
\text { shivening and } \\
\text { stiffesess }\end{array}$ & $\begin{array}{l}\text { Ulceration in } \\
\text { mouth }\end{array}$ & - \\
\hline
\end{tabular}

Table: Like Disilike:

\begin{tabular}{|c|c|c|c|c|c|}
\hline S.N. & Question & $\begin{array}{c}\text { Age of } \\
\text { Assessment }\end{array}$ & Vatujaju Prakiti & Pittujaja Prakititi & Kaphojaj Prakirit \\
\hline 1. & Liked disilike & After 6month & $\begin{array}{l}\text { Music and } \\
\text { scented area }\end{array}$ & Hate sunlight & ․․….... \\
\hline 2. & $\begin{array}{l}\text { Like and } \\
\text { disilike feeding }\end{array}$ & After6month & $\begin{array}{l}\text { Like sweet, } \\
\text { pungent and hot } \\
\text { food }\end{array}$ & $\begin{array}{l}\text { Like sweet, bitter. } \\
\text { astingent, cold } \\
\text { foodd drinks }\end{array}$ & \begin{tabular}{|l} 
Likep pungent, \\
bitter, astringent, \\
hot and non-olly
\end{tabular} \\
\hline
\end{tabular}

Table 10: Body parts:

\begin{tabular}{|c|c|c|c|c|c|}
\hline S.N. & Question & $\begin{array}{l}\text { Age of } \\
\text { Assessment }\end{array}$ & Vataja Prakriti & Pittaja Prakriti & Kaphaja Prakriti \\
\hline 1. & Physique & $\begin{array}{l}\text { From } \\
\text { registration }\end{array}$ & $\begin{array}{l}\text { Thin, } \\
\text { Underdeveloped } \\
\text { ugly }\end{array}$ & Delicate Body & $\begin{array}{l}\text { Compact and stable } \\
\text { body, all organs are } \\
\text { well } \\
\text { developed/Good } \\
\text { looking }\end{array}$ \\
\hline 2. & Skin texture & $\begin{array}{l}\text { From } \\
\text { registration }\end{array}$ & Rough and dry & $\begin{array}{l}\text { Soft, moist skin } \\
\text { with moles and } \\
\text { pimples (neonatal } \\
\text { acne vulgaris) }\end{array}$ & Thick, soft and oily \\
\hline 3. & Skin color & $\begin{array}{l}\text { From } \\
\text { registration }\end{array}$ & $\begin{array}{l}\text { Dusky, luster } \\
\text { less and dark } \\
\text { complexion }\end{array}$ & Coppery color & $\begin{array}{l}\text { Fair color like } \\
\text { Durva, Indrayava } \\
\text { and Privangu }\end{array}$ \\
\hline 4. & Hair & After 6 month & $\begin{array}{l}\text { Scanty, Thin, dry } \\
\text { and dusky }\end{array}$ & $\begin{array}{l}\text { Fine, soft, early } \\
\text { greying or falling } \\
\text { or no hair }\end{array}$ & $\begin{array}{l}\text { Dark, thin, dense, } \\
\text { oily. Hair are curly } \\
\text { and blue like bees }\end{array}$ \\
\hline 5. & Eye color & After 6 month & $\begin{array}{l}\text { Dry, Dusky, not } \\
\text { beautiful and } \\
\text { like dead }\end{array}$ & $\begin{array}{l}\text { Coppery color } \\
\text { and rounded }\end{array}$ & $\begin{array}{l}\text { Broad, beautiful } \\
\text { and reddish at their } \\
\text { end angles }\end{array}$ \\
\hline 6. & Palm and sole & $\begin{array}{l}\text { From } \\
\text { registration }\end{array}$ & $\begin{array}{l}\text { Rough and } \\
\text { cracked }\end{array}$ & Coppery color & Thick and soft \\
\hline 7. & Lips & $\begin{array}{l}\text { From } \\
\text { registration }\end{array}$ & $\begin{array}{c}\text { Rough and } \\
\text { unstable }\end{array}$ & Coppery color & Broad and thick \\
\hline 8. & Body part & $\begin{array}{l}\text { From } \\
\text { registration }\end{array}$ & $\begin{array}{l}\text { Calf muscles are } \\
\text { small in size and } \\
\text { hard }\end{array}$ & $\begin{array}{l}\text { Joints and } \\
\text { muscles areloose }\end{array}$ & $\begin{array}{l}\text { Broad forehead, } \\
\text { well developed, } \\
\text { long arm and leg }\end{array}$ \\
\hline 9. & Nail & $\begin{array}{l}\text { From } \\
\text { registration }\end{array}$ & $\begin{array}{l}\text { Rough, hard, } \\
\text { thin, small and } \\
\text { dusky }\end{array}$ & Coppery color & $\begin{array}{l}\text { Whitish, soft and } \\
\text { shining }\end{array}$ \\
\hline
\end{tabular}

Scores of Vata, Pitta and Kapha in infants were attained by using a $0 / 1$ against $\mathrm{V} / \mathrm{P} / \mathrm{K}$ for each of the questions depending on a no or yes answer respectively. Cumulative scores of $\mathrm{V}, \mathrm{P}$ and $\mathrm{K}$ are calculated through the percentage of manifested Dosha in infants. Criteria to define the Prakriti in infant, on the basis of Dosha percentage has been followed as per protocol [25].

\section{E. Assessment of Prakriti by computer-aided tool (PRS-IPA):}

The developed software is a complete package for helping users/ Kaumarbhritya expert (Ayurvedic Pediatrician) in analyzing infants' Prakriti. Platform used for development of the software is Microsoft Visual Basic 2010, Express Edition, which is a part of Visual Studio 2010package and can run in higher version too. Many components and various methods were used for developing the software [26] [27] [28]. This software also uses same questionnaire as per manual method for determination of Prakriti in infants.

\section{F. Statistical analysis:}

Validation of Prakriti assessment software (PRS-IPA) was done by Infant's Prakriti Assessment questionnaire (IPAQ), a newly developed Infants Prakriti Assessment Proforma. Validation was done by Spearman's Rank Correlation Coefficient and Cohen's kappa coefficient. Validation by Spearman's Rank Correlation coefficient was found highly significant. Level of agreement by Cohen's kappa coefficient is also significant. Kappa value was determined to perceive the consistency of results among the Ayurvedic pediatrician who assesses the Prakriti by using hard copy proforma and questionnaire designed in software (PRSIPA).

Published By:

Blue Eyes Intelligence Engineering

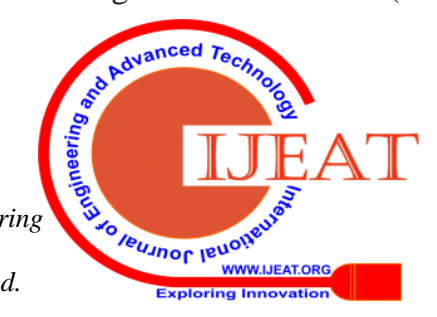




\section{OBSERVATION \& RESULT}

Table 1l: Validation of data gathered from the questionnaire inculcated in PRS-IPA with the manually congregated data by Spearman's rank correlation coefficient

\begin{tabular}{|c|c|c|c|c|}
\hline $\begin{array}{c}\text { Registered Cases } \\
(\mathrm{n}=226)\end{array}$ & Mean \pm SD & Median & $\begin{array}{c}\text { Range } \\
\text { (Min-Max) }\end{array}$ & $\begin{array}{c}\text { Correlation } \\
\text { coefficient }\end{array}$ \\
\hline $\begin{array}{l}\text { V-Software } \\
(\mathrm{n}=226)\end{array}$ & $24.96 \pm 14.67$ & 17.67 & $2.42 \cdot 68.15$ & \multirow[t]{2}{*}{$0.000(\mathrm{HS})$} \\
\hline $\begin{array}{l}\text { V-Questionnaire } \\
(\mathrm{n}=226)\end{array}$ & $26.73 \pm 14.12$ & 18.18 & $4.54-68.18$ & \\
\hline $\begin{array}{l}\text { P- Software } \\
(n=226)\end{array}$ & $37.1 \pm 19.6$ & 41.885 & $10.04-73.91$ & \multirow[t]{2}{*}{0.000 (HS) } \\
\hline $\begin{array}{l}\text { P-Questionnaire } \\
(\mathrm{n}=226)\end{array}$ & $37.97 \pm 19.37$ & 45.44 & $11.11-77.77$ & \\
\hline $\begin{array}{l}\text { K-Software } \\
(\mathrm{n}=226)\end{array}$ & $42.69 \pm 18.29$ & 49.4 & $10.71-76.16$ & \multirow[t]{2}{*}{$0.000(\mathrm{HS})$} \\
\hline $\begin{array}{l}\mathrm{K} \text {-Questionnaire } \\
(\mathrm{n}=226)\end{array}$ & $42.48 \pm 18.54$ & 47.82 & $8.69-73.91$ & \\
\hline
\end{tabular}

Kappa correlation: - The kappa statistic is frequently used to test inter-rater reliability and itmeasures level Agreement

\begin{tabular}{|c|c|}
\hline Value & Approx. Significance \\
\hline 0.955 & $\mathrm{p}=0.000 \mathrm{HS}$ \\
\hline
\end{tabular}

The mean \pm SD of percentage of Vata, Pitta and Kapha was $24.96 \pm 14.67,37.1 \pm 19.6$ and $42.69 \pm$ 18.29 respectively by software(PRS-IPA), while by Infant's Prakriti Assessment questionnaire (IPAQ), this was $26.73 \pm 14.12,37.97 \pm 19.37$ and $42.48 \pm$ 18.54 respectively.

On applying correlation coefficient for assessment of Prakriti by software and questionnaire, significant correlation was observed in all the Prakriti. Details of median and minimum and maximum range of these data gathered from the software and by using Infant's Prakriti Assessment profoma can be seen from table number 1 . When Cohen's kappa coefficient was applied to assess the validity of Prakriti assessment by software and questionnaire, its value was found 0.955 which is highly significant according to Fleiss's guidelines that means Prakriti assessed by PRS-IPA software is valid [29].

\section{DISCUSSION}

Knowledge of Prakriti (Physical constitution) may go a long way in health maintenance by making one aware of suitable and unsuitable substances applicable on a one-to-one basis [30]. Now, the concept of Prakriti has better understood in terms of its genomic and biochemical correlations and ensuing clinical applications [31] [32] [33] [34]. PRS-IPA (Prototype Research Software-Infant Prakriti Assessment) is a complete package aimed at helping users (pediatricians) in analyzing Prakriti of infants and also assisting in differentiating the physiological features from the pathological features through basic data analysis. The developed prototype software is a complete package which utilizes Microsoft Visual Basic 2010 Express and Microsoft Excel. Visual Basic is used as a platform for creating and working with the forms. Microsoft Excel is used for details of the patient. Results of this study suggest that newly designed tool tested in a fair number of samples is reasonably reliable and valid on statistical analysis. The Prakriti was first determined by Infant's Prakriti Assessment questionnaire (IPAQ) by manual method and after that Prakriti was determined by PRS-IPA software for each individual, then comparison between the IPAQ and PRS-IPA was made which revealed a highly significant agreement of 0.955 (95.5\%) concordance.

\section{CONCLUSION}

Prakriti has decisive role in restoration of health, which is a prime objective of Ayurveda. Based on the results, it may be concluded that PRS-IPA is a validated tool for Prakriti assessment in infants which shall be helpful for data storage, time saver and accurate analysis in its determination. The analysis of Prakriti of an infant based on the entered data will ensure the better planning for individualized management and forecast the possibility of Prakriti dependent diseases in future.

\section{ACKNOWLEDGEMENTS}

Authors are thankful to all the parents of infants who have given consent for participated in the study.

Source of Support: None

Conflicts of interest: None Declared

\section{REFERENCES}

1. Agnivesha, Charaka, Dridhabala, Charaka Samhita, Viman-Sthan 8/94, edited by Vaidya Jadavaji Trikamj Acharya.Varanasi:Chaukhambha, Surabharati Prakashana; 2008.

2. Kunte AM, Navare KS. Reprint edition. Ashtanga Hridaya of Vagbhatta with Sarvangasundara commentary of Arundutta. SutraSthana; Chapter 1: Ayushkamiyadhyaya, Verse 9. Varanasi: Chaukhambha Sanskrita Sansthana; 2016.

3. Agnivesha, Charaka, Dridhabala, Charaka Samhita, Viman-sthan 6/16, 7/4, edited by Vaidya Jadavaji Trikamji Acharya.Varanasi: Chaukhambha Surabharati Prakashana; 2008.

4. Agnivesha, Charaka, Dridhabala, Charaka Samhita, Sutra-sthana, 10/11, edited by Vaidya Jadavaji Trikamji Acharya.Varanasi: Chaukhambha Surabharati Prakashana; 2008.

5. Vagbhatta, Ashtanga Hridaya, Sutra-sthan 1/10, edited by Anna Moreshwar Kunte. Varanasi: Chaukhamba Sanskrita Pratishthan, 2009.

6. Agnivesha, Charaka, Dridhabala, Charaka Samhita, Sutra-sthana, 7/4, edited by Vaidya Jadavaji Trikamji Acharya.Varanasi: Chaukhambha Surabharati Prakashana; 2008.

7. Agnivesha, Charaka, Dridhabala, Charaka Samhita, Viman-sthana, 8/95, edited by Vaidya Jadavaji Trikamji Acharya, Varanasi: Chaukhambha Surabharati Prakashana; 2008

8. Sushruta. Sushruta Samhita, English translation by Sharma P.V, Vol II, Sharir-sthan (4:64), Chaukhambha Vishvabharati , Varanasi. 2005

9. Agnivesha. Charaka Samhita, English translation by Sharma RK Dash B. Vol-II, Viman-sthan (8:95), Chaukhambha Sanskrit series office, Varanasi. 2010

10. Agnivesha. Charaka Samhita, English translation by Sharma RK, Dash B. Vol-I, Sutra Sthan (7:41-44), Chaukhambha Sanskrit series office, Varanasi. 2010

11. Sushruta. Sushruta Samhita, English translation by Sharma P.V, Vol II, Sharir-sthan (4:62), Chaukhambha Vishvabharati , Varanasi. 2005.

12. Srivastava Niraj, Singh Praguna, Gehlot Sangeeta, Singh Sanjay, Singh B.M: Basics for the development of prototype research software relevant to infants' Prakriti assessment for Vikriti management and possible future disorders. Int. J. Res. Ayurveda Pharm. 8 (Suppl 1), 2017 
13. Agnivesha. Charaka Samhita, English translation by Sharma RK, Dash B. Vol-1, Viman Sthan (8:96-100), Chaukhambha Sanskrit series office, Varanasi. (2010)

14. Sushruta. Sushruta Samhita, English translation by Sharma P.V, Vo II, Sharir-sthana (4:64-76), Chaukhambha Vishvabharati , Varanasi. (2005)

15. Vagbhata. Astanga samgraha, English translation by Srikantha Murty KR, Vol-II, Sharir-sthana, (8/6-14), Chaukhambha Orientalia , Varanasi. (2001)

16. Vagbhata . Astanga Hridaya, English translation by Srikantha Murty KR, Vol-I, Sharir-sthana (3:85-103), Chaukhambha, Krishnadas Academy Varanasi. (2015).

17. Bhavmishra. Bhavprakasha, commentary and English translation by Sitaram Balusu, Chunekar KC ,Vol-I Purva-khanda 4:54-58, Chaukhambha Orientalia , Varanasi. (2006).

18. Sharangadharacharya. Sharngadhara Samhita English translation by Rao G. Prabhakar, 1st edition, Purva-khanda (6:21-23), Chaukhambha Sanskrit sansthan, Varanasi. (2013).

19. Harita. Harita Samhita English translation by Pandey Gyanendra , Vol-1, Pratham-sthana 5:17-22, Chaukhambha Sanskrit series office, Varanasi. (2016).

20. Bhela, Bhela Samhita. English translation by Krishnamurty K.H, Viman-sthana ,4:16-25, Chaukhambha Vishvabharati , Varanasi. (Reprint year 2008)

21. Srivastava Niraj, Gehlot Sangeeta and Singh B. M. Affiliation among Infantile Age, Morbidity and Prakriti (Physical Constitution): A Longitudinal Preliminary Study; | Vol 19 (1) | January 2019

22. Piyush Kumar Tripathi, Sangeeta Gehlot. "A Physio-anatomica study of Prakriti, ID- 21024805, www.luiu.com,2017.

23. Sushruta. Sushruta Samhita, English translation by Sharma P.V, Vo I, Sutra-sthan (10:4), Chaukhambha Vishvabharati , Varanasi. (2005).

24. Vagbhata. Ashtanga Samgraha, English translation by Srikantha Murty KR, Vol-I, Sutra sthana, (1/45.1), Chaukhambha Orientalia , Varanasi. (2001).

25. Srivastava N, Gehlot S, Singh S, Singh BM. Do the anthropometric parameters vary as per Prakriti (Physical constitution) of Infants; International Journal of Innovative Knowledge Concepts, 5(12) December, 2017

26. Halvorson, Michael 2010. Microsoft Visual Basic 2010 Step by Step. MicrosoftPress,2010

27. Mayo, Joe. Beginner's Guide Visual Studio. ISBN 13: 9780071668958. Publisher: Mc Graw- Hill Education, 2010.

28. Tylee, Lou. Learn Visual Basic 6.0.KID ware, 1998 http://www.kidwaresoftware.com/index.htm

29. FleisJ.L. Statistical methods for rates and proportions (2nd edition).NewYork:John Wiley.1981.

30. Pine D. Nashville, Tennessee: Introduction of Ayurveda to Chiropractic, Building a functional bridge, Proceedings of the Sacro Occipetal Technique Research Conference; 2011. pp. 86-101.

31. Acharya YT, editor. Vimana-Sthana 8/95, Varanasi: Chaukhambha Orientalia; 1997. Charak samhita; pp. 277-78.

32. Acharya YT, editor. Sharira-Sthana 4/65-76, Varanasi: Chaukhambha Sanskrit Sansthan; 2007. Sushruta-samhita; pp. 36162.

33. Caldecott T. Ayurveda: The divine science of life. Elsevier Health Sciences. 2006:27-34.

34. Nambodiri N, editor. Varanasi: Chaukhambha Krishndas Academy; 2010. Ashtang Hridaya, 3/84-102; pp. 193-195.

\section{AUTHORS PROFILE}

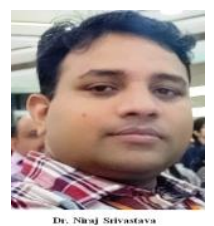

Dr. Niraj Sivastava, has completed his BAMS and MD (Ay) Kaumarbhritya/Balroga from Faculty of Ayurveda, Institute of Medical Sciences, Banaras Hindu University (BHU), Varanasi, India, in 2005 and 2008 respectively. He has completed the Ph.D (Kaumarbhritya) in supervision of Prof. B.M Singh in 2017 from Department of Kaumarbhritya, BHU, Varanasi, India. Currently he is working as a Professor in Department of Kaumarbhritya, at Saradar Patel Institute of Ayurvedic Medical Sciences \& Research Centre. He has published 54 research papers in various journals, 10 chapters in book and 3 books. His area of expertise includes Prakriti assessment in children, Swarnaprashana etc.

Praguna Singh, (Software Engineer) has completed his B. Tech in Computer Science from Manipal Institute of Technology (MIT), Karnataka row India, in June 2016. Currently he is working as a Developer in SAP Labs India Pvt. Ltd, Bengaluru, Karnataka, India. His area of expertise includes Programming Languages (C, C++, Java, Python, JavaScript, Nodejs, VB.Net, C\#), Frameworks (UI5, Spring, React, Keras) and Platforms (Cloud Foundry, SAP Cloud Platform) etc.

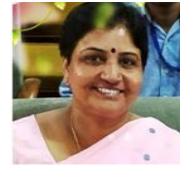

Prof. Sangeeta Gehlot, is working as Professor \& Head, Department of Kriya Sharira, Faculty of Ayurveda, Institute of Medical Sciences, Banaras Hindu University (BHU) Varanasi, India. She has completed the MD (Ay) \& Ph.D (Kriya-Sharir) from department of Kriya-Sharira, BHU, Varanasi, India. She has published more than 87 research papers in various national and international journals, 10 chapters in different books and has published 7 Books. Her area of expertise includes Prakriti, Exercise Physiology, Ayurveda Education, Diabetes mellitus. She has supervised $10 \mathrm{MD}$ thesis and $13 \mathrm{Ph} . \mathrm{D}$ thesis.

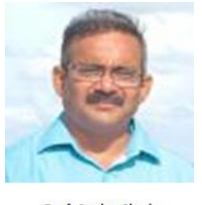

Prof. Sanjay Singh, is working as Professor in Department of Computer Science and Engineering, Indian Institute of Technology (IIT-BHU), Varanasi, UP, India. He has published 55 research papers in various journals, 12 chapter in book and 2 patents. His area of expertise includes watermarking scheme for image tampered detection and localization with recovery capability and soft biometrics based multimodal recognition system etc.

Prof. B.M Singh, is working as Professor\& Head, Department of Kaumarbhritya/Bal roga, Faculty of Ayurveda, Institute of Medical

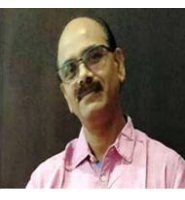

Prof. B.M Singh

Diarrhea etc. Sciences, Banaras Hindu University (BHU) Varanasi, India. He has completed the MD (Ay) \& Ph.D from department of Prasuti Tantra (Kaumarbhritya Unit), BHU, Varanasi, India. He has published more than 40 research papers in various national / internationa journals, 10 chapters in book and 4 books. His area of expertise includes Prakriti assessment in children, Childhood Asthma, management of cerebral palsy,

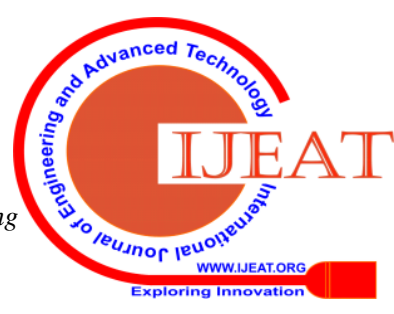

